indeed endorse the two principles, or at least priority to the worst-off. This is questionable: the considerable effort Rawls devotes to attacking utilitarianism is evidence that there is at least one reasonable alternative to the two principles derivable from the original position. Minor — and not unreasonable changes to some of the assumptions of the original position would likely yield other conceptions of justice. It is paradoxical that Audard emphasizes tolerance of competing reasons for endorsing a particular conception of justice, but is much less tolerant in relation to the chosen conception.

Despite the huge secondary literature on Rawls there are still relatively few works that attempt a broad interpretation of his project. Exceptions are recent books by Thomas Pogge and Samuel Freeman. Audard offers an interesting and valuable addition to the list.

Paul Graham

University of Glasgow, UK

\title{
Infinitely Demanding: Ethics of Commitment, Politics of Resistance
}

Simon Critchley

Verso, London, 176pp.

ISBN: 9781844671212.

Contemporary Political Theory (2008) 7, 451-456. doi:10.1057/cpt.2008.10

This short book is a bold attempt to construct a new ethics for the present based on a Levinasian framework. It begins by setting out a strong assertion of the basis of ethical action. In order to be effective, it is not enough for an ethical position to have justifications; it must also entail an emotional or psychological commitment to act (pp. 24-26). This is provided by the 'ethical experience'. According to Critchley, the core of moral selfhood is this 'ethical experience', an experience of an encounter with radical otherness, an (unmeetable) demand by the other that is recognized by the self. It is this experience that binds the self to what it takes to be its good (pp. 8-9), a relation that is constitutive of the self (pp. 20-21). Hence, the self does not coincide with the body (p. 86). It is split between the self as such and the demand of the other, or ego and superego (p. 89). Ethical experience occurs as the approval of a demand, with the demand and its approval being mutually constitutive (pp. 16-18). Further, it is constitutive of the subject. There is something at the heart of the self that is opaque, incomprehensible and 'external' (pp. 61-62). The basis of ethical action is thus responsibility and 'ethical outrage', not freedom (p. 125). This conception is explicitly contrasted with the traditions of 
ethical thought based on autonomy, particularly Kantianism; immanentism is also rejected as identical to fullness (p. 118).

Having set out this ethical framework, Critchley then constructs an account of what he takes to be its political consequences. Here, he remains broadly within a radical democratic framework, but departs significantly from the Laclauian emphasis on political order. He embraces Laclauian hegemony, suggesting that political articulation is necessary amidst fragmentation and dislocation (p. 102). Capitalist development does not unify but rather diversifies oppositional subjectivities (p. 91). 'The political task... is one of inventing a name around which a political subject can be aggregated from the various social struggles through which we are living' (pp. 103-104). Hence the state is constitutive in constructing social identities, even those, such as indigenous identities, which are constructed oppositionally (pp. 105-106). He does also say, on the other hand that society is the basis for the state, not the other way around (pp. 115-116). But what integrates the social force as an oppositional force is a logic of hegemony, a positing of universality, and hence, a politics of demand (p. 114).

However, this statist, ordering moment is only one half of what Critchley proposes. He also seeks to open a 'space of dissensus' or 'event of politics... that the state order always wishes to shut down' (pp. 110-111), an interruption not a continuity of the ontological domain (p. 147). For Critchley, politics is not simply about order; it also means dissensus, multiplicity and delegitimation (p. 13). The current social system is suffering from 'drift, disbelief and slackening' and is experienced as externally compulsory but not internally compelling (p. 39). In other words, there is a libidinal gap between the social system and its subjects. The spectacle has become utterly pervasive, and politics is now largely fantasmatic, 'politics as the control of visibility' (pp. 134-135). The discourse of the war on terror is based on a fantasy scenario of a threatened homeland that is constructed through the management of fear (p. 136). He is convinced that the right's electoral success reveals a better understanding of politics than the left (pp. 98-99).

Against scepticism about the possibility of politics today, Critchley claims that politics is 'now and many'; in other words, it is everywhere (p. 131). Politics requires an interstitial distance from the state, and hence, resistance to the state's colonization of social space (p. 92). 'Working at an interstitial distance from the state, a distance that I have tried to describe as democratic, we need to construct political subjectivities that are not arbitrary or relativistic, but which are articulations of an ethical demand whose scope is universal' (p. 132). Distance from the state is defined as democratic, indeed, as the meaning of democracy, the truth of the state that no state incarnates (pp. 114-115). The distance is to occur as an 'enactment of cooperative alliances, aggregations of conviviality and affinity at the level of society' (p. 117). 
Critchley associates this moment of the event or of interstitial politics with 'anarchic metapolitics', such as anarchist-inspired social movements. Despite this supportive appreciation of the democratic role of anarchism, however, this is not an anarchist account. Critchley recognizes but then dismisses the anarchist critique of the state, basically simply because he thinks the anarchocommunist version is unworkable and unrealistic (pp. 111-112, 148). Politics hence becomes a matter of distance from the state, but this distance is to be a distance within the state, an interstitial distance (p. 113). His view of the state is mistaken; he views a state as something 'we inhabit' (p. 111), rather than a specific apparatus that rules over people. Anarchy cannot, therefore, be a principle, but can only disrupt the state (p. 122). The goal is to 'better' or 'attenuate' rather than overthrow the state, to 'materially deform' its power (p. 117). Like Žižek, he seeks to socialize, not destroy, capital (p. 99). Like Hardt and Negri, he seeks to pass through, not resist, the transformations brought on by capitalism (p. 100). This is partly because he seems to think we need capitalism to show us contingency and relationality. As part of this strategy, Critchley demands that resistance stop short of both violence and overthrow (pp. 124, 147). Instead, the language of rights can be used to create 'levers of political articulation' by 'raising a universal claim' against a particular injustice or wrong (p. 91). This anarchic metapolitics is also supplemented by a rather more vigorous, less hesitant call for assertive mainstream politics in which he denounces the American democrats as not vicious enough and calls for a 'leftist populism' to counter the neo-conservative agenda (p. 144).

The limits of the text are built into the approach taken. Critchley's method is ultimately reductive and speculative; philosophy dictates to the processes of becoming rather than following from them. In many regards, this is an exercise in royal science, in the traditional preoccupations of the isolated theorist, and is almost precritical in its metatheoretical standpoint - business as usual for political theory. The problem is exacerbated by the fact that most of the issues discussed are not really issues of philosophy at all. Most are actually libidinal issues dressed up in metaphysics, and would be better dealt with psychologically. A reader has reasons to be suspicious of this choice of vocabulary. Whereas metaphysics slips easily into absolutisms, psychology is contingent, and the theorist is compelled to take account of intercultural and interpersonal variance to a greater degree than Critchley here attempts. Similarly, Critchley's opponents or interlocutors here are all philosophers themselves. He does not attempt to connect his theory of ethics to everyday life, moral economy, the critique of common sense and so on. In other words, this is theory in abstraction from social life. Maybe Critchley's approach can lead to anarchism between people, but not within people; it has not yet reached the point of beheading the king in the field of philosophy. 
Critchley's ethical account is unconvincing in that it is unclear what basis (if any) he has for taking the experienced demand of the other, the opaque core of the self, the separation of self and body and other such categories to be universal to all humans, across cultural, subcultural and psychological difference. While much actually-existing ethical action may indeed conform to this model, a Nietzschean or Deleuzian objection can be raised to the assumption that all ethical attachment necessarily takes this form; the possibility of an active ethics is foreclosed in advance. Critchley could thus be viewed as still in the world of reactive morality, related to a transcendental moment, and not even at the point of asking the questions that would be needed to begin constructing an active, non-moralizing ethics. Hence for instance, Richard Day in Gramsci is Dead calls for an approach that rejects the ethics of demand so central to Critchley's account, instead seeking to break with reactive attachments to the state. Of course, such an approach would also have to examine some of the issues Critchley raise, but an opposition to silencing and disempowerment and a resultant dialogical relation to the other would not necessarily have to derive logically from a prior submission to a demand conceived in alterity; it could also be about realizing a kind of world one wants to see, or even the expression of a relational self that views its own construction as dialogical and as 'becoming-other'. This is a political as well as a theoretical problem. There is a danger that the metaphysical vision of the self could be turned into an ideal against which people are judged, with the fidelity to the imaginary other transmuting into an intolerant judgement of the actually-existing other for not even attempting to meet an unfulfillable demand, for being excessively immanent.

Critchley presents his account as a matter of breaking down the autonomous self, but there are limits to how far he does so. Critchley's self is 'dividual', split into parts and not an autonomous whole; nevertheless, these parts are limited to two, ego and superego, and not the kind of plural relations and subjectpositions that arise from networks of affinity and from relational epistemologies and intertextualities. In other words, it is 'dividual', non-unitary, but is still a molar self. Critchley does not consider either the contingency and nonuniversality of the molar self or the costs involved in its socio-familial construction, leaving open the suspicion that his account might be a retrospective mythologization that justifies a rather different process of violent subjectification of the reactive self (a process that may itself be immoral by Critchley's standards, denying the voice of the other, such as the child, inmate, psychiatric patient or colonized people undergoing subjectification). In this, his thought is in far greater continuity with the Kantians and egoists he denounces than with the more radical streams of poststructuralism, and probably more than he would be able to admit. 
As a theory of permanent dual power, Critchley's theory is certainly a step forward from the unreconstructed statism of the likes of Laclau. He at least realizes the need for social forces to constrain the state and for non-state affiliations and spaces to be constructed and defended - something all too infrequent both in 'radical democratic' theory and contemporary liberalism. It is a recognition at last of the importance of the distinction between social (or affinity) and political (or hegemonic) principles. Critchley is also to be commended for taking these 'newest' social movements seriously, despite their distance from his own political conception. Perhaps, the decay of supposed liberal democracies has gone so far that liberals are looking to anarchist movements as a source of hope.

The weakness of this recognition, however, lies precisely in its supplementary construction - the social or affinity principle is never allowed to escape the grip of the state; it is in effect reduced to the role of supplement, something that enriches the state order by bringing it something it is unable to provide to itself, but is ultimately constrained from developing as an organizing principle in its own right or from challenging this order. Hence, the largely unsupported assertion of the impossibility of overthrowing the state, the persistent conflation of the more radical kinds of activism with nihilism, and the obvious discomfort with the importance of autonomy as a theme in anarchist thought.

Critchley provides a depiction of the functioning of radical activism that is in empirical terms largely accurate - the usual operation of activist resistance is interstitial, consists in creating spaces at a distance from the state, constraining state power and putting forward rights and claims. Often, however, the aspiration is more than this - in European autonomism for instance, it involves the creation of self-valorization autonomous from capital and the state, and of lived spaces that are outside state control; in indigenous movements it often includes goals of socio-cultural independence. Among 'neoanarchist' activists, one is likely to find few who self-identify with Critchley's image of resistance that remains consciously interstitial, does not seek to overthrow the state and limits itself to claims to rights and justice. Rather, one finds something closer to Richard Day's depiction of a logic of affinity pitted against the logic of state sovereignty and the politics of demand, a kind of insurrectionary total opposition aspiring to root-and-branch transformation (an opposition found even in those anarchist writers, such as Colin Ward and Hakim Bey, whose strategies are most explicitly interstitial). What is more, the interstices are those of the social order as a whole, not interstices within the state - a small but crucial distinction. The point is most often to create forms of life outside the state by finding interstices in the territory and population that it might claim to rule, but without being able to actualize the claim. In this, the state is as radically exterior to 'neo-anarchism' as to classical anarchism maybe even more so. One might say that Critchley provides an external, 
observation-based theory of the being of anarchist and anti-capitalist activism, but is unable to provide an internal account of its becoming, or its operation as a social force.

Hence, Critchley is mistaken in his construction of the relationship between the state and social forces; he underestimates the externality of state and social intentionalities relative to each other, and he mistakes an unstable modus vivendi arising from the collision of a line of flight with an apparatus of capture for the line of flight itself. Hence, he stops lines of flight at a certain point the point of being the state's conscience (or supplement). And instead of the direct relations between social forces and political movements, Critchley ends up with a mythical politics of interconnection (the enemy of the state as the bearer of the truth of the state) that is politically unhelpful because its implications are somewhere between confusion and reformism.

The account of social movements, especially indigenous movements, is sorely lacking not only because of its peremptory character but also because it effectively reduces the concepts involved to empty signifiers. The discussion of indigenous movements does not explore the crucial distinction between indigenous and metropolitan worldviews, or the extensive anthropological scholarship (such as the work of Sahlins, Clastres and Lee) that problematizes the assumption that the universality of transcendentalism includes indigenous societies. Such analyses would drastically undermine the view of capitalism as bringing contingency and articulation to previously non-historical societies, a Eurocentric prejudice underlying the account of modernity that Critchley draws from theorists of democratic revolution. His account effectively reduces the difference between indigenous and metropolitan movements to the choice of a different 'name' or master-signifier, completely ignoring the everyday aspect of identity construction, the role of specific indigenous epistemologies and the struggle between immanent and transcendent attitudes to nature. He repeats the reductionism of Laclauian theory, treating every social movement as an outgrowth of a particular structural matrix with simply the names or signifiers changed.

In conclusion, the approach set out by Critchley is both important and limited. It is important because Critchley is perhaps the first theorist to show the necessity of anarchic resistance for democracy, and because it breaks the hegemony of strong forms of statism in radical-democratic theory. It is limited in that it is tied to a metaphysical reduction of politics that preaches rather than practises openness to difference, and because it ultimately recuperates radical struggles by reducing them to the secondary role of the conscience or supplement of the state. 